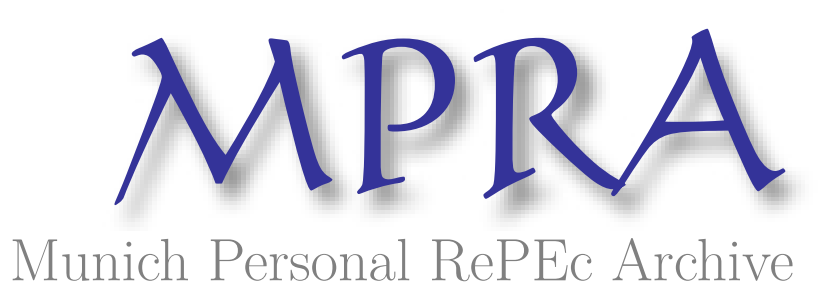

\title{
A Short History of the Global Economy Since 1800
}

\author{
Alam, M. Shahid \\ Northeastern University, Boston, MA 02115
}

June 2003

Online at https://mpra.ub.uni-muenchen.de/1263/

MPRA Paper No. 1263, posted 28 Dec 2006 UTC 


\title{
A Short History of the Global Economy Since 1800
}

June 2003

This paper presents a schematic history of the global economy since 1800. The economic and political logic of global capitalism in this period is defined by its ability to derive a growing share of its energy from fossil fuels. The explosive growth of this period, the dominance of capital, the growing military superiority of centers of capitalist growth, and the widening disparities in the global economy are ultimately driven by the logic of fossilbased capitalism. From 1800 to 1950, the global economy experienced growing centralization of capital and power, dividing the global economy into an advanced and dominant Center and a backward and subordinate Periphery. A period of decentralization follows from 1950 to1990, when most segments of the Periphery regained various levels of control over their economies. Since the early 1990s, the forces of centralization have gained the upper hand.

\author{
M. Shahid Alam \\ Professor of Economics \\ Northeastern University, Boston, MA 02760 \\ m.alam@neu.edu
}

Key Words

Global economy, fossil-fuels, centralization, Periphery, Center, Imperialism, Karl Marx

JEL Codes

N0, O1, F0, B0

CM. Shahid Alam 

This is a short history of the global economy since 1800. It is about the system of global capitalism that took shape once the British economy went 'underground' and began to draw its energy and, increasingly, its raw materials from mineral resources.

The progressive substitution of minerals for plants, as the economy's source of energy and raw materials, transformed the dynamics of capitalism. It opened up vast new sources of energy and raw materials, freeing the economy from the narrow resource constraints of an organic, plant-based economy. The new cheaper, more abundant energy produced dramatic reductions in the costs of transportation; a growing volume and range of goods could now enter into long-distance and international trade; and this rapidly created the basis for an international division of labor. But the resource substitution also deepened the logic of uneven development. On the one hand, the mineralbased economy created several positive feedbacks that strengthened the already existing tendency towards the division of trading areas into Core and Periphery, or concentrations of high and low value-added activities. In addition, it augmented the military power of the states that pioneered these new technolgies. Together, these tendencies-markets, energy substitution, and force-created the modern global economy, increasingly integrated but also deeply divided into a Core and Periphery. ${ }^{1}$

The history of the new mineral-based global economy falls into three phases, defined with reference to the degree of global centralization of power. The first phase, lasting from 1800 to 1945 , concentrated power - and, with it, capital, technology, science and manufactures - in a small number of Core areas, notably Britain, France, United States, and Germany. Conversely, the greater part of the Periphery - nearly all of Asia and Africa-lost its sovereignty to a few Core countries, was forced to open their

1 The terms, organic and mineral-based economy, are borrowed from Wrigley (1988: 12). 
economies to Core capital, specialized in primary goods, and scarcely experienced any improvements in the living standards of the indigenous population. The global economy slowly entered into a second phase in the late 1940s, although this process was initiated earlier with the Russian Revolution of 1917, when power was decentralized from the Core to the Periphery. On the level of the economy, this decentralization reversed the earlier concentration of manufactures in the Core countries, and produced dramatic acceleration of growth in the dependent Periphery. Starting in the 1980s, however, power was again recentralized in the Core countries. Already, by the mid-1990s, this re-centralization had exceeded the previous peak in the global centralization of power attained during the late nineteenth century. This paper will examine these three movements of the global economy, though the emphasis will be on analyzing the dynamics of the third movement.

\section{Two Economic Logics}

It is important to begin by laying out, if only briefly, the different logics underlying the organic, land-based economy that held center stage before 1800 and the inorganic, mineral-based economy that has been developing since that date.

In the old agrarian system, two factors perennially constrained its capacity for economic growth. This system drew nearly all its energy from plants, the source of our food, fuel, fiber and other raw materials; this constrained the supply of energy since the land necessary for growing plants was available only in finite quantities. In addition, this system only used organic instruments, men and animals, for converting the energy captured by plants into mechanical energy. These organic instruments did not favor growth since their upkeep required large amounts of land, and their efficiency at converting energy 
could scarcely be improved upon. As a result, once all accessible land had been brought into use, the agrarian system grew by improving the organization of work, primarily through division of labor; inventing machines that enhanced the efficiency of work; or improving the quality of existing lands. The division of labor offered the best prospects for growth, though this was limited - as Adam Smith so famously noted-by the extent of the market, or transportation and institutions of exchange. Most importantly, once all the land was in use, the limits on growth pressed harder. It was land, or its ability to fix solar energy through plants, that appeared to impose the final constraint on growth in this organic economy.

The new inorganic economy that developed after 1800 transcended the dual limits that constrained growth in the organic economy. It drew its energy and raw materials increasingly from stocks of minerals, and since these stocks were quite large relative to the rate at which they could be drawn down, this virtually lifted the cap on energy flows available to the economy. More importantly, the energy from fossil fuels was converted to mechanical energy by machines: the steam engine and, later, internal combustion engine. Once these machines outstripped the organic instruments for converting energy to work, they found growing applications in transportation, manufacturing, and, eventually, agriculture. In time, the cheaper energy, when combined with advances in science and technology, produced cheaper inorganic substitutes for organic raw materials. This was in addition to the uses of fossil fuels, which began at an earlier date, in heating homes, lighting and smelting.

This energy revolution created a variety of positive feedbacks. First, the fossil fuels freed land from producing fuels and fodder; the development of inorganic substitutes for organic raw materials had the same effect. In other words, even as the new economy expanded, it released land that could be used for pro- 
ducing more food and organic raw materials, and we can expect this to reduce the industrial economy's propensity to imports of food and raw materials, at least during the early stages of this development. Second, the cheaper energy reduced the costs of manufacturing and transportation; in turn, the cheaper transportation produced cumulative cost reductions in manufacturing through wider markets, greater division of labor, technology spillovers, and other linkages. These cumulative cost-reductions and, in part, their localized effects, created a tendency to concentrate the world's manufactures in countries - the Core countries - that took an early lead in harnessing the new energy. Conversely, the rest of the world, the Periphery, specialized in producing food and raw materials, still using the old source of energy. Finally, the new energy per se stimulated endless innovations in production technology. Since large and increasing amounts of energy could now be concentrated at one point in space, this led to the development of larger, faster, and more powerful machines for use in transportation, manufacturing, mining, construction and, eventually, agriculture. This constituted a third source of cumulative growth in the industrial economy.

The energy revolution had created a new economic dynamics. Unlike the muscle-driven, plant-based, land-constrained agrarian economy, the industrial economy increasingly drew upon minerals for its energy and raw materials, employed engines to convert fossil fuels to mechanical energy, and used this energy to mechanize work in manufacturing, transportation, construction, and agriculture. The productive capacity of the industrial economy was not constrained by energy, as in the old agrarian economy, but by its ability to deploy machines that converted energy to work. The engine of growth in this economy was capital accumulation, since this determined how fast it could expand the stock of energy-converting and energy-using 
machines available to the economy. As a result, capitalists replaced landlords as the central actors in the new industrial economy.

These profound changes created new classes and class conflicts. The new energy-converting and energy-using machines downgraded the workers in manufacturing even as they pushed this sector to the center of the economy. Of course, the workers were still needed, but the new machines diminished their importance. Now the workers could not own their machines, which were too expensive compared to what they were able to save individually. The craftsmen, artisans, and even peasants, became labor, hired by capitalists to tend to the machines, fix them when they broke down, or perform tasks that had not yet been mechanized. The machines-and their capitalist proprietors-now employed the workers. In addition, since the new energy created concentrations of factories, it also assembled great masses of workers in one workplace. These conditions favored the growth of class consciousness on both sides of the production process.

The industrial economy deepened the polarizing tendencies in the agrarian system. Formerly, due to the greater economies of scale in manufactures compared to primary goods, there was a tendency for manufactures to be concentrated in countries which acquired the biggest markets, whether by chance or force. By reducing the costs of manufactures and transportation and creating mineral-based substitutes for raw materials, the energy revolution strengthened this tendency. In addition, both directly and indirectly, the energy revolution added to a country's military power by stimulating prosperity, reducing the cost of arms and armaments, and improving military technology as inventors drew upon the general advances in the economy's technical capabilities. In time, the development of steamboats, better prophylactics against tropical diseases, and the development of rapid-firing weapons sealed the fate of Africa and Asia; they 
were colonized or converted into open-door countries. ${ }^{2}$ The white-dominated Periphery in Europe and Latin America had the protection of membership in the European family of civilized nations. ${ }^{3}$

The first countries to adopt the new energy system would have a near-lock on the global economy. It created a set of cumulative forces that concentrated manufactures, capital, technology and power in the countries that took a lead in the energy revolution - the Core countries. Simultaneously, the new energy system created a Periphery, economic regions that were restructured by Core capital to supply food, agricultural raw materials and minerals to the Core. In varying combinations, military force, markets and racist ideologies brought about this restructuring. It is the story of this global economy that we narrate in these pages.

\section{Karl Marx and Class Contradictions}

In his Wealth of Nations, Adam Smith (1776) does not once refer to any of the early signs of an industrial revolution - the harnessing of waterpower, the use of steam engine in mines, or the rise of factory production. Although he was greatly impressed by the power of division of labor in manufacturing, he believed that diminishing returns to capital and labor, in the presence of fixed amounts of land, would eventually lead the economy into a stationary state. This remained the vision of classical economists even as late as the middle of the nineteenth century.

Amongst classical economists, Karl Marx (1848) alone took serious notice of the industrial revolution. In graphic passages, he describes the quickening pace of history, the tremendous expansive power of capital, its constant search for new markets

${ }^{2}$ Headrick (1981).

${ }^{3}$ Strang (1996)). 
and new technologies, and how this was pushing small-scale producers into the ranks of workers, and unleashing profound changes in the economic and social landscape of pre-capitalist societies everywhere. These transformations had produced two great classes, capitalist and workers, constantly at odds with each other. At the global level, this expansive dynamic was destroying pre-capitalist societies and binding them into a single system of global markets. Although Marx did not worry too much about the origins of capitalism - he saw its precursors in the burghers of medieval towns, the growing commerce stimulated by the discoveries, and the system of Atlantic trade-he was reasonably certain that the system he was describing was fully developed or nearly so. Indeed, it was ready for another epochal transformation, and he might even live to see that happen in his own lifetime. As it was, Marx underestimated the durability of the system he was analyzing.

Class contradictions are central to Marx's analysis of capitalism. The two great classes spawned by industrial capitalism, capitalists and workers, had opposite interests. The capitalists were driven by competition to accumulate, innovate, and expand their market shares; this produced concentrations of capital and deepening business cycles. By the same logic, they sought to drive down wages and lengthen the workweek; this pauperized the workers. At some point, Marx predicted, even in his own lifetime, these two tendencies would produce a proletarian revolution. Led by the communist party, the workers would overthrow the capitalists, abolish markets, socialize ownership and production, and lay the foundations of a new social formation.

History did not oblige Karl Marx. There would be no proletarian revolutions in the advanced industrial countries, where capitalist contradictions were most ripe for the overthrow of capitalism. The workers stirred in less likely places, but were 
easily suppressed. On the whole, the class contradictions were contained, as capitalist growth created a middle class, and rising labor productivity began to translate into higher wages for production workers. In time, when the workers organized, it was not to overthrow the system but to demand higher wages and better working conditions. Slowly, capitalists acceded to these demands, as unionized power expanded, workers gained voting rights, and labor parties gained ground at the ballot. The emergence of the Soviet Union, the first worker's state, pushed Core capital towards greater accommodation with their working classes. In addition, since there was little industrialization in the Periphery yet, their concessions to labor did not dampen the international competitiveness of Core capital. Finally, with help from compulsory schooling and the media, the system succeeded in socializing the workers as citizens, endowed with rights and the illusion that they were free to move up the social ladder through education, thriftiness and hard work.

\section{Imperialist Rivalry}

The challenges to Core capital came from two sources not anticipated by Karl Marx: the rivalry of countries seeking entry into the Core, and attempts by the Periphery to overthrow the Core's hegemony.

The outward expansion of Core capital was a central result of Karl Marx's analysis of capitalism. He never worried that anything short of a proletarian revolution could reverse this expansion; it would penetrate all parts of the world, and transform and launch them on development trajectories similar to those traveled by the Core countries. Karl Marx had not foreseen that the global expansion of Core capital, in and of itself, might generate contradictions that would reverse for several decades the capitalist penetration of the Periphery. We are indebted to 
Vladimir Lenin and the neo-Marxists for drawing out attention to these contradictions.

Contrary to the mythical accounts of orthodox economists, we observe an intimate connection between the capital and the state at least in the rise of capitalism in Western Europe. In the new age heralded by the energy revolution, capital in the Core countries would use the expanded powers of the state to try to acquire exclusive control over markets and resources in the Periphery. Starting in the nineteenth century, this produced a new wave of direct colonization of societies - in Asia, Africa and Caribbean - that did not have the protection of membership in the Western "family of nations." At least for a while, the parceling of the world into colonies proceeded quite smoothly. There was plenty of real estate for everyone.

The first challenge emerged when powerful new entrants into the Core - Germany, Italy and Japan - were seized with empire envy. The old timers, Britain, France and Netherlands, had appropriated all the real prizes in Africa and Asia. Miffed, the newcomers decided that their best chance of gaining an empire was to take it from those who had one. In time, as Britain's hegemonic control weakened, this produced two fratricidal World Wars, fought mostly amongst Western countries at the Core. According to an African proverb, when elephants fight, the grass gets trampled on. In this case, whether by good or ill luck, the grass would have a chance to grow.

\section{Core-Periphery Contradictions}

Industrial capitalism spawned powerful cumulative processesoperating through markets, military power and racist ideologies of domination - which concentrated capital, manufactures, technology and power in the Core countries. The dependent Periphery in Asia, Africa and the Caribbean, regions that lost their sov- 
ereignty, specialized in the production of primary goods for export.

The centralizing tendencies of Core capital acted strongly and quickly. By 1913, according to Bairoch (1982: 296, 304), twothirds of the world's manufactures were concentrated in four Core countries: Britain, United States, Germany and France. In 1750, their combined share had stood at less than a tenth. At the same time, the Core countries reduced vast areas of the worldnearly all of Asia, Africa, Central America and the Caribbeanto colonies, open-door countries or dependencies, which were converted to the production of primary exports. Those parts of the Periphery that enjoyed various degrees of political autonomy were luckier. By 1950, many of them had developed indigenous capital, skills and manufactures.

The contradiction between the Core and dependent Periphery was on display, most transparently, in the widening gap between the living standards of the two economic areas. According to Bairoch (1981), Britain had roughly the same per capita income as Asia in 1800; but, in 1950, it had gained a lead of close to six to one. Africa suffered a similar decline in its relative position. On an average, the sovereign parts of the Periphery did not face a decline in their relative position during this period.

Once again, history had dashed the great hopes of Karl Marx. Core capital had penetrated the Periphery -in fact, its political penetration of the dependent Periphery was nearly completebut failed to transform its productive potential. Instead, the global expansion of Core capital had polarized the world, dividing it into two unequal moieties, the Core and the Periphery, connected by the disequalizing impact of trade, imperialism and racist ideologies. In the words of Andre Gunder Frank, capitalist development at the Core produced underdevelopment in the Periphery. It is important to note that this inverse dynamic was 
strongest in the relations between the Core countries and the dependent parts of the Periphery.

The prospects for growth in the dependent parts of the Periphery were dim as long as they could not structure their economic relations with Core capital. Yet, the system itself offered a break. Help came when the elephants got into fights - big fights, better known as World Wars. These wars battered the strength of the elephants, creating opportunities for indigenous capital in the Periphery. When these wars directly involved major countries in the Periphery - Russia in the First World War, and China in the Second World War - they created openings for the emergence of radical political movements. Thus was born the October Revolution of 1917, amidst the chaos of Russian defeat during the First World War, producing the first systemic challenge to Core capital. Ironically, the challenge had come from the Periphery.

The October Revolution of 1917 began a temporary reversal in the global concentration of capital, power and manufactures. It gave an impetus to liberation movements - in the colonies and open-door countries - that were already challenging this concentration, even pushing some towards radical solutions. The Soviet Union stood as the vanguard, the one great ally, of liberation movements seeking to roll back the colonial empires and weaken the polarizing dynamic of global capital. When the elephants fought again twenty years later, these decentralizing movements were poised for major victories.

Most importantly, the Second World War battered the major colonial powers, those who won no less than those who lost. Of course, the defeated powers, Italy and Japan, instantly lost all their colonies. The victorious colonial powers, Britain, France, Belgium and Netherlands, found that they had lost too much of their former strength to successfully defend their empires, especially as the liberation movements gathered steam. In most 
cases, they decided to pull out of their colonies before the anticolonial movements turned violent; this also offered the best opportunity of preserving their economic interests and influence in the former colonies. A massive decentralization of power followed, larger, more dramatic and deeper than the one that marked the dismantling of Spain's American empire in the 1820s.

This was a window of opportunity for the Periphery, especially the former colonies and open-door countries who were now free to restructure their relations with Core capital. Several tried collective ownership and planning, and insisted on a radical break from global markets. By the 1970s, nearly a third of the world's population lived in communist countries. Many more did not reject markets as such, but adopted a variety of interventionist measures to develop indigenous capital, manufactures and skills. Starting in the 1950s, the former colonies jettisoned the colonial doctrines of laissez faire, free trade, balanced budgets, and private ownership. In their place, they introduced interventionist policies to accelerate the pace of development.

This decentralization produced some dramatic results. The share of the Periphery - Africa, Latin America, and Asia minus Japan - in world manufacturing output had shrunk to 6.5 percent in 1953 from a dominant share of 73 percent in 1750. After two centuries of decline, this share began to increase in the 1950s, and rose to 12 percent in 1980. In addition, the growth rates in the Periphery accelerated dramatically. The per capita income in the largest colonies and quasi-colonies, containing some 50 percent of the world's population, grew at an average annual growth of 0.5 and -0.27 percent over 1900-1913 and 19131950; the same growth rates for the sovereign countries in the Periphery were 1.61 percent and 1.34 percent. Over 1950-1992, the growth rates in the former colonies and quasi-colonies had 
jumped to 2.96 percent, ahead of the 2.58 percent recorded for the always-sovereign countries in the Periphery. ${ }^{4}$

\section{Re-Centralizing Power}

The retrenchment of Core capital would not last. Starting in the 1980s, the IMF and World Bank began to dismantle the developmental states as their mounting international debts pushed them closer to bankruptcy. A decade later, the communist regimes began their transition to markets. In 1994, the creation of WTO institutionalized the interests of Core capital.

It is tempting to take the position that this recentralization was inevitable. An underdeveloped Periphery could not long resist the expansive power of the Core countries once the latter had recouped their war losses and regained their growth momentum. Yet, the communist revolutions and the liberation movements in the Periphery came quite close to dislodging global capitalism. On closer examination, the argument that revolutions in the Periphery were incapable of overthrowing Core capital is not as watertight as it appears. In this case, Core capital had geopolitical luck on its side.

The challenge from the Periphery was quite massive. The Soviet Union, which mounted the systemic challenge to global capitalism, was a great power itself. Its industrial and military strength expanded rapidly in the decades following the Revolution, and, at the end of the Second World War, it had emerged as one of the two superpowers dominating the world. In 1950, the communist regimes in Soviet Union, Eastern Europe and China stretched continuously from the Danube and the Balkans to the Pacific, together controlling the upper half of the Eurasian landmass; they also contained nearly a third of the world's

4 The data in this paragraph are from Alam (2000): 151, 169. 
population. In addition, communist parties were active in many Third World countries. At this point, many fully expected the tide of communism to roll westward into a Europe devastated by war, and southward into impoverished Asia and Africa. If, instead, Core capital successfully blocked the communist advance and the Soviet Union itself collapsed in 1990, there was nothing inevitable about these outcomes.

If Core capital overcame the communist challenge, this was, at least in part, a fortuitous outcome of the system of nation states. The fact that United States was the hegemonic power during this crucial period was a geopolitical accident; there was nothing in the logic of capitalist system per se that produced this result. Yet, this accident was of vital importance to the outcome of the contest between Core capital and the communist regimes and nationalist liberation movements in the post-war years. Imagine this contest with Britain still as the leading Core country.

United States brought several vital advantages to this contest. The most important was size. It had vastly greater resources than its predecessor, Britain, had at its height. United States produced 44.7 percent of the world's manufacturing output in 1953 and 27 percent of the world's output in 1950; compare this to Britain's peak share of world manufacturing output of 20 percent in 1860, and a share of 8.5 percent in world output in 1870.5 American capitalism too was in some ways unique; it had a huge industrial working class but they possessed little classconsciousness. As a result, organized American labor joined enthusiastically in the fight to undermine workers' movements overseas. Capitalism - 'free enterprise,' in the American lingooccupied a place in this country's emotional life that normally

5 The data on shares of manufacturing output are from Bairoch (1982: 296, $304)$, and the data on shares in world output are from Maddison (1994): 1823, 227. 
belongs to religion, inseparable from its national existence and history. The communist challenge evoked very strong emotional defenses. Finally, the great distance of United States from the theatres of war in Europe ensured that it would emerge from the two World Wars with all its industrial assets in one piece.

The American strategy for containing communism required the commitment of massive resources. The first component of this strategy was to put the war-devastated economies of Western Europe and Japan back on their feet; some of these economies had lost more than half of their pre-war production capacities. The Marshall Plan was the centerpiece of these efforts. The United States injected $\$ 11.8$ billion into Western Europe between 1948 and 1952, equal to $\$ 120$ billion in 1997 prices. ${ }^{6}$ In the words of Duignan and Gran (1997), this amounted to the "greatest voluntary transfer of resources from one country to another." This injection of capital financed technology transfers and the import of vital machinery, spare parts, and raw materials, all of which put Western Europe's industries back on their feet by 1952. In addition, the Marshall Plan pushed Western Europe towards economic and political cooperation, helping to lay the foundations of a united Europe. United States played a similar role in the recovery of Japan.

The second focus of America's containment strategy was a massive military buildup. During the Cold War, the military spending of United States remained roughly proportional to its share in the global economy. In 1986, this share was 28 percent of the world total and 65 percent of the NATO total. It is even more remarkable that the Soviet Union, according to CIA estimates, outspent the United States. In 1986, the military expenditures of United States and Soviet Union were \$365 billion and $\$ 374$ billion respectively. ${ }^{7}$ Since the Soviet GDP was only 38 per-

6 The data are from Duignan and Gran (1997).

7 The data on military expenditures are from Conetta and Knight (1997). 
cent of the US GD in 1986, this must have placed their civilian economy under considerable strain. ${ }^{8}$ Many experts maintain that this was an important factor in the eventual collapse of the Soviet Union.

The containment strategy had a third focus. On the one hand, it consisted of massive efforts to install anti-communist governments in the Periphery, prop them with military and economic assistance, and use them to eradicate radical movements in their own countries. The White House led these efforts with support from several agencies including the United States Agency for International Development (USAID). The Central Intelligence Agency (CIA) carried out the opposite task of overthrowing or destabilizing governments that were 'unfriendly' to United States. A single statistic bespeaks better than many tomes the power of this Agency: it spent $\$ 26.6$ billions in 1997.9

The vast economic and military resources of United States allowed it to maintain a firm hegemonic grip over the global capitalist system. On the one hand, it created the NATO (North Atlantic Treaty Organization) to institutionalize its military dominance over the Core countries in Western Europe. In a similar move, Japan was converted into a military protectorate. In the economic arena, United States sought to stimulate economic growth in Western Europe and Japan by providing them relatively free access to its own vast markets. In other words, the United States employed its dominant hegemonic position to eliminate military conflicts among Core countries and, in addition, replaced their economic rivalries with various cooperative arrangements, including the European Common Market (ECM) and the Organization for Economic Cooperation and Development (OECD). Freed from their old conflicts, with declining trade barriers, and better management of business cycles, the

8 Maddison (1995): 183, 187.

9 Levin (1997). 
Core countries went on to experience a golden period of growth between 1950 and 1973.

Core capital slowly regained its intellectual confidence and political muscle as it grew and expanded, at home and abroad. On the economic front, this was visible in the assault by neoclassical economists on Keynesian macroeconomic policies, the regulation of industries, the welfare state and social security programs. Politically, Core capital gained control over the levers of power with the election of Prime Minister Thatcher in 1979 and President Ronald Reagan in 1980, two right-wing warriors. The conditions were now ripe for Core capital to stage a comeback.

We can agree on the factors that contributed to the collapse of communism but still disagree on their relative importance. First, and I think foremost, there was the geopolitical luck that placed the vast resources of the United States in the fight to contain communism. This not only stopped the spread of communism: it pushed the Soviets into a debilitating military rivalry even as they failed to match the growing affluence offered by the Core countries. In addition, the communist states were disadvantaged in their ideological battle against Core capital. The Core countries captured the high ground on democracy and freedoms, even while they sterilized the impact of these rights with moneydriven elections, media manipulation, and schooling. On the other hand, the communists practiced inflexible planning, rejected political competition, and stamped out dissent with police methods. They denied workers a sense of ownership in their workplace, and when they also failed to deliver prosperity, they had no chance of surviving. It was too late when the Soviets undertook reforms in the late 1980s; this only deepened the feeling that the system was indeed rotten, and hastened its collapse. China avoided this catastrophic end by starting early on their economic reforms and delivering rapid economic growth. How- 
ever, their reforms too led to the same destination: the dismantling of communism.

The end of developmental states came about differently. They had created hothouses for the growth of indigenous capital in the Periphery, a prospect that could not have pleased the Core countries. Since Core capital could not block the progress of developmental states, they sought to penetrate them with official loans, military agreements, private investments, technical assistance, and access to the best graduate schools in the Core countries. In time, this would produce results. Core capital penetrated the key sectors of the developmental states, integrated their elites into the lower rungs of the Core hierarchy, and oriented their most talented graduates into Core labor markets. Once started, this process worked by undermining the developmental states.

Several forces inside the developmental states produced similar results. In their anxiety to deliver growth on the cheapwithout painful reforms - the nationalists would seek loans from the Core countries, regardless of the hidden costs, until their debt servicing placed them at the mercy of the lenders. In their search for easy profits, the indigenous bourgeoisie forged links with Core capital - as subsidiaries, suppliers, and distributors and, once these ties multiplied, they would lobby for the removal of barriers against the penetration of Core capital. Finally, as some developmental states created the infrastructure and skills that would make them increasingly competitive in manufactures-threatening the Core countries with competition in their own markets-this would invite predatory investment from Core capital, eager to ensure that they owned the new industries developing in the Periphery. The strikes against developmental states were mounting.

The dismantling of developmental states began in the early 1980s, well before the end of the Cold War. It was triggered by 
the cumulative impact of the two oil crises of 1974 and 1979. Unable to pay their higher import bills, the oil-importing developmental states took out variable-interest loans from foreign banks secured by sovereign guarantees. When interest rates rose in 1981, and some of these countries faced bankruptcy, the IMF and World Bank - the watchdogs of Core capital-stepped into the breach, offering new loans to stop them from defaulting on their old ones. At first, the borrowers were required to stabilize their economies, which translated into cuts in their social spending. This was the thin end of the wedge. In time, the conditionalities were expanded into "structural adjustment programs" - a code word for eviscerating the developmental states - which required eliminating trade barriers, freeing exchange markets, privatization, and national treatment of foreign investments.

The age of neoliberal economics had arrived. This was the new consensus forged in the 1980s by a cohort of orthodox economists, many connected to the World Bank and IMF. For several years, they had been developing a doctrinaire neoclassical critique of developmental states - supported by several generously funded, country-by-country assessments of the inefficiency of interventionist policies in the developmental states. Their vision, appropriately dubbed the "Washington Consensus" by John Williamson (1994), would tilt the playing field in the Periphery to favor Core capital. In this new regime, the reformed states would guarantee national treatment to Core capital, enforce property rights - effectively, those of Core capitalbalance their budgets, and help in the provision of human capital. Core capital would step in to capture the commanding heights - the financial sector, utilities, communications-and any industry that offered handsome profits.

The end of the Cold War produced a push to institutionalize the interests of Core capital in a new global framework. In 1994, this led to the creation of the World Trade Organization (WTO), 
which bound all its members to a single set of rules - neoliberal rules - on trade, exchange markets, foreign investments, government procurements, property rights and investments. The WTO forced all countries to accord "national treatment" to imports and foreign capital in every sector of the economy, including services, thereby preparing the ground for rolling back the gains of developmental policies. All this was a signal departure from the General Agreements on Trade and Tariffs (GATT) - the trade regime displaced by $\mathrm{WTO}$ - which granted developing countries the right to impose protectionist trade and payments regimes.

By the late 1990s, Core capital had reversed much of the decentralization of power that had occurred since 1917. At no period during the past two centuries did Core capital-not even during its previous peak in the late nineteenth century-operate with so much freedom in nearly every country of the world, or make deeper inroads into the Periphery. In effect, the WTO bound the Periphery to the old open-door treaties minus extraterritoriality; though in other respects the WTO was more invasive than the open-door treaties, especially in the enforcement of property rights, the penetration of services, and opening up government contracts to foreign bids. In addition, the private agglomerations of Core capital in the 1990s were now incomparably greater-compared to most countries in the Peripherythan they were a hundred years back. This increased the capacity of Core capital to crowd out, co-opt and absorb indigenous capital in the Periphery. Was this the Valhalla of Core capital, the dream of the prophets of laissez faire?

\section{Recentralization: Economic Consequences}

Contrary to the grandiose claims made by the ideologues, the neoliberal, open-door economic regimes imposed on the Periph- 
ery by Core capital - starting in the 1980s - have produced no economic miracles. Instead, these economic regimes have brought economic ruin or, at best, lack-luster performance to the countries they have touched most deeply.

In order to identify the failure of neoliberal economics, we will compare the growth record of the Periphery in the two decades before and after 1980. First, consider the two decades preceding 1980 when nearly all countries in the Periphery protected their manufactures, regulated their currency markets, engaged in deficit spending, and their governments took on entrepreneurial roles. By the norms of neoliberal economics, they violated all the rules of good economic housekeeping. Yet, they recorded quite impressive growth rates under these interventionist regimes. The GDP of low-income countries grew at average annual rates of 4.6 and 4.5 percent during the 1960s and 1970s; the corresponding figures for the middle-income countries were 6.0 and 5.6 percent. There were no strong regional variations in the growth record for this period. Although growth in Sub-Saharan Africa faltered during the 1970s, there were nine countries in this region whose average annual growth rates exceeded 5.0 percent during this decade. ${ }^{10}$

Over the next two decades, as the World Bank and IMF forced neoliberal policies upon them, the growth rates in the Periphery declined in proportion to their embrace of these policies. The neoliberal policies took their first toll in Latin America and Sub-Saharan Africa. Both regions suffered a precipitous decline in their GDP growth rates to 1.7 percent during the 1980s, producing declining per capita incomes. The growth rates in Latin America recovered during the 1990s to 3.4 percent per annum, though this was significantly below their pre-1980 levels. The growth rate for Sub-Saharan Africa improved only marginally

10 World Bank (1983): 150-51. 
during the 1990s, and it was unable to stem the decline in its per capita income. ${ }^{11}$

The collapse of Eastern Europe and Central Asia came next, with their rapid integration into global capitalism starting in the 1990s. Their economic decline was striking. Although the growth performance of these economies had been weakening for some time, they still managed to log an annual growth rate of 2.4 percent in their GDP during the 1980s. However, their precipitate transition to markets produced catastrophic results. During the 1990s, their GDP declined at an annual rate of 2.7 percent, more than wiping out the gains of the previous decade. It is doubtful if any economic region of comparable size has experienced a similar decline in its output. Soon, their fertility rates fell significantly below replacement levels, producing a declining population. ${ }^{12}$

The economic decline of the Middle East and North Africa since the 1980s has been nearly as steep as in Sub-Saharan Africa. Their GDP growth rates in the two decades after 1980 were significantly below those for the two preceding decades. As a result, the region's per capita income declined between 1980 and 2000. This was not due to declining oil prices alone. The non-oil economies in this region shared in this decline; their GDP had grown at 2.9 percent annually between 1950 and 1980, but this declined to 1.5 percent in the two decades after 1980. This decline occurred at a time when the non-oil economies, barring Syria, were liberalizing their trade and payments regimes. ${ }^{13}$

Most countries in East and South Asia, which had made striking progress in the transition to neoliberal economic regimes,

\footnotetext{
11 World Bank (2001): 295.

12 World Bank (2001): 295, 297.

13 Sevket Pamuk, The Middle East and North Africa in the age of globalization, 19802000 (Paper presented at the $13^{\text {th }}$ IEHA Congress at Buenos Aires, August 2002): http://www.eh.net/XIIICongress/cd/papers/7Pamuk 421. pdf
} 
followed the same pattern. Their growth rates in the two decades after 1980 were visibly lower than in the two preceding decades. Notably, this group includes the most advanced countries in the region-Taiwan, South Korea, Singapore, Hong Kong, Thailand and Malaysia - as well as the poorer countries: Sri Lanka, Indonesia, Philippines and Pakistan.

There were few countries in the Periphery that escaped the declining trend in growth rates in the post-1980 period. India and China, the two largest countries in the Periphery with more than one-third of the world's population, nearly doubled their GDP growth rates in this period compared to their record in the three previous decades. Although both countries enacted market reforms since 1980, they were still amongst the most illiberal economic regimes in the world, whether one examines the extent of state ownership in their industries or their trade and payments regime. ${ }^{14} \mathrm{~A}$ second group of countries-Myanmar, Laos and Vietnam-experienced dramatic upturns in their growth rates during the 1990s, without the benefit of a liberal regime.

These results should surprise no one but the historically myopic. In the hundred years before 1950, the colonies and opendoor countries performed poorly compared to the sovereign countries in the Periphery - those that were generally free to choose interventionist policies. ${ }^{15}$ During the post-war interlude lasting into the 1970s, when most of the former colonies and open-door countries practiced strongly interventionist policies,

14 Wacziarg and Welch (2002) maintain that India and China remained closed economies as of 2000-India more than China — when judged in terms of their average tariffs, non-tariff-barriers, and exchange-rate premiums. In addition, state-ownership remained dominant in heavy industries in India; in China, this included the financial sector as well.

15 The average annual growth rates of PCI in the sovereign countries were 1.00 percent for 1870-1900, 1.61 percent for 1900-1913, and 1.34 percent for 19131950. The corresponding figures for the colonies and open-door countries were 0.59, 0.50 and -0.27 . Alam (2000): 151. 
they experienced a dramatic acceleration in their growth rates. It is scarcely surprising that the forced return to open-door policies in the Periphery, since the 1980s, has repeated the results from the past. It is not clear how long India and China, the two major countries that have not yet surrendered their economic sovereignty, can resist conversion to neoliberal economic regimes.

The re-centralization of power by Core capital that began in the 1980s was quite swift and mostly non-violent, unlike the centralization that reached its peak in the last decades of the nineteenth century. Perhaps, this is not surprising. The first centralization was a pioneering movement: it involved the creation, extension and deepening of core-controlled systems of transport, trade, finance, investment, cultural instruments, and subordinate classes in the Periphery. It took centuries to establish this system, often involving wars. However, when the colonial powers departed from their colonies, in most cases, they did not fully liquidate these long-established systems of control. While they terminated direct political controls, and ended their military presence, many of the economic and social linkages, though weakened, persisted in most former colonies; only the communist countries severed nearly all their linkages with Core countries. This is what made the second re-centralization easier.

The Core countries began to reinforce their informal systems of control as soon as they lowered their flags over their former colonies. The reinforcements took many forms, including foreign aid, military assistance, joint military exercises, training programs, and foreign investments. When Core countries, now working in unison, articulated their new determinationthrough IMF, World Bank and the OECD - to impose neoliberal regimes on the former colonies in the 1980s, there was little resistance. For the most part, the elites in the Periphery had already been integrated into the hierarchy of power emanating from the Core; they also understood that resistance carried unacceptable 
costs. There was no popular resistance because re-centralization did not affect the visible symbols of sovereignty. The communist countries too were re-integrated without firing a shot. They were overthrown from within, since they failed to deliver prosperity, freedom or a sense of ownership.

\section{Concluding Remarks}

The swift and easy recentralization of the global economy created a paradoxical situation. United States still commanded a massive military force while the combined military strength of its main adversaries was less than a third its former size. ${ }^{16}$ This led to calls to downsize the military, an intolerable prospect for the industries whose profits depend on military contracts. This had to be remedied.

The refurbished power of Core capital was creating some domestic problems too. On the one hand, Core capital was eroding the social gains made by workers, consumers, and environmentalists since the 1930s. More importantly, the labor force in the Core countries was beginning to face competition from the growth of industrial production and advanced skills in some countries at the Periphery. They were also losing jobs as Core capital relocated to the Periphery, a process being accelerated by the internet revolution. In addition, Core capital was using its muscle to import cheaper skilled workers into the markets of Core countries. Faced with a sustained decline in their living standards - the first in the history of industrial capitalism-a growing number of people in the Core countries were gravitating towards anti-Corporatist, anti-globalization movements. This too had to be remedied.

16 In 1994, according to Conetta and Knight (1997) US military expenditure was $\$ 288$ billion, while that of Potential Threat States was $\$ 167$ billion; in 1986 the corresponding figures were $\$ 365$ billion and $\$ 550$ billion. 
These problems would be solved by inventing new enemies. It was in this context that Bernard Lewis (1990) first invented the "clash of civilizations" between the West and Islam. He argued that the Islamist opposition in the Middle East represented "a mood and a movement far transcending the level of issues and policies and the governments that pursue them. This is no less than a clash of civilizations - the perhaps irrational but surely historic reaction of an ancient rival against our Judeo-Christian heritage, our secular present, and the worldwide expansion of both in 1990, that the West was engaged in a veritable clash of civilization with Islam." Three years later, Samuel Huntington (1993) generalized this thesis into a historical principle. At the end of the Cold War, he prophesied, the world is entering a new age, whose conflicts will occur along the fault lines of civilizations, mostly between the West and Islam, and the West and China.

The Clash thesis set up the military machine for capture by powerful special interests and voting blocks within United States. Quickly, the Israeli lobby, Christian fundamentalists, the oil interests, and military contractors joined forces. Each would pursue its specific goal-eliminating threats to Israel's hegemony, Christianizing Islamic societies, capturing oil profits, resisting military cuts-by mobilizing America's redundant military to re-colonize the Middle East. It was not hard selling this imperialist project to Americans. The Arab regimes were easily painted into a corner. They were tyrannies, they possessed weapons of mass destruction, they were an imminent threat to American lives, they opposed Western values, and they threatened Israel. A great nation, the greatest there has ever been, would have little difficulty manufacturing a clash of civilizations when it needed one. 


\section{References:}

Alam, M. Shahid, Poverty from the Wealth of Nations (Houndsmill, UK: Macmillan, 2000).

Bairoch, Paul "The main trends in economic disparities since the Industrial Revolution," in: Paul Bairoch and Maurice LévyLeboyer, eds., Disparities in economic development since the Industrial Revolution (New York: St. Martin's Press, 1981).

Bairoch, Paul, "International industrialization levels from 1750 to 1980," Journal of European Economic History 11, 2 (Spring 1982): 269-333.

Conetta, Carl and Charles Knight, Post-Cold War US military expenditure in the context of world spending trends (Project on Defense Alternatives: January 1997): http:/ / www.comw.org/pda/bmemo10.htm\#2.

Duignan, Peter and Lewis H. Gran, “The Marshall Plan," Hoover Digest 4 (1997): http://www-hoover. stanford.edu/publications digest 974 duignan.html

Headrick, Daniel R., The tools of empire: Technology and European imperialism in the nineteenth century (New York: Oxford University Press, 1981).

Huntington, Samuel, "The clash of civilizations?" Foreign Affairs (Summer 1993).

John Williamson, eds., The political economy of policy reform (Washington, D. C.: Institute for International Economics, 1994).

Levin, Duncan, "The CIA and the price we pay: Law-suit response puts the figure at $\$ 26.6$ billion, Baltimore Sun (October 19 , 1997):

http://www.gwu.edu/ cnss/secrecy/dloped.html.

Lewis, Bernard, "The roots of Muslim rage," Atlantic Monthly (September 1990).

Smith, Adam, The wealth of nations: An inquiry into the nature and 
causes (Modern Library: 1776/1994).

Strang, David, "The social construction of sovereignty," in: Thomas J. Biersteker and Cynthia Weber, eds., State sovereignty as social construct (Cambridge: Cambridge University Press, 1996).

Wacziarg, Romain and Karen Horn Welch, "Trade liberalization and growth: New evidence (Palo Alto: Stanford University, November 2002): http://www.stanford. edu/ wacziarg/ down loads/ integration. pdf.

World Bank, World Development Report, 1983 (New York: Oxford University Press, 1983): 150-51.

World Bank, World Development Report, 2000-2001 (New York: Oxford University Press, 2001).

Wrigley, E. A., Continuity, chance and change: The character of the industrial revolution in England (Cambridge: Cambridge University Press, 1988). 